\title{
Classification and Evaluation of Wadi Abu Omira Soils, West of Matrouh North Western Coast, Egypt
}

\author{
Gihan. M. Ebied and Taher. M. H. Yossif ${ }^{1}$
}

\begin{abstract}
The northwest coastal region of Egypt is one of the most promising areas for agricultural development that due to its distinction in that it has all the resources and components of development available in one place.The study area was carried out on Wadi Abu Omira locate in the north western coast of Egypt west Marsa Matruh city to identify the geomorphic units and landforms in the study area as well as, classified the soils according to their taxonomy and land capability. The study area occupies an area of $\mathbf{1 6 0 0}$ feddan and landforms were determined by geomorphological and topographical maps. Twenty three profiles have been selected to represent the main landform units in the soils study. The study area could be categorized by two orders namely Entisols and Aridisols. The Aridisols subgroups namely classified as Typic haplocalcids, lithic Torripsamments and Typic Torripsamments. The main diagnostic horizons of Aridisls are calcic horizons while Entisols are less developed soils. The different properties of the study area are profile depth, texture and topography properties, three soil mapping units were differentiated, deep coarse to moderately coarse textured, moderately deep coarse to moderately coarse textured, shallow coarse to moderately coarse textured soil. The field investigations showed that, $11.00 \%$ of the studied area has deep profile, moderately deep $38.00 \%$ while shallow depth covers only $51.00 \%$. Regarding to the texture of the soil under study, $55.26 \%$ to 44.73 of the area were sandy loam to loamy sand soil and the rest of area has either sand or sandy clay loam texture. Most of the area considered non saline to slightly saline and the studied area is moderately calcareous to extremely calcareous. According to USDA (1962), the study area classified into four capability classes II cover 154 feddan $(9.63 \%)$, III cover 199 feddan $(12.43 \%)$, VII cover 637 feddan $(39.81 \%)$ and VIII cover 610 feddan (38.13\%). According to FAO (2006), the current suitability of these soils can be placed at class S1 (slightly suitable), S2 (moderately suitable) S3, (marginally suitable) and $\mathbf{N}$ (unsuitable). The most limiting factors in the studied soils are profile depth, salinity index (EC), and available water (AW) while the rest limitation factors represent minor limitations. The present study is a trial to evaluate soil potentialities of this region in terms of land capability classification. In future such work will be useful as around basis for agricultural development policy of that region.
\end{abstract}

Key words: landforms, Soil classification, Soil potentialities, Soil capability, Soil suitability

\section{INTRODUCTION}

Egypt has a total area of about million $\mathrm{Km}^{2}$, of which only a small area concentrated around the Nile Valley (4\% of the total area) is agriculturally productive area and the rest area is desert. The major challenge which Egypt faces today is the need for better development and management of natural resources, to meet the needs of a growing nation. Consequently reclamation of desert lands is one of the most important strategic initiatives in Egypt. The target of land reclamation and water management development is to increase Egyptian farm land (Pautsch and Abdelrahman, 1998).

The development could be give more successful if it far away of the soil which adjacent to the Nile Valley. In this respect, the North Western Coastal considers one of the regions that could be the solution to increase the agriculture land in Egypt. At present, northwestern coastal zone of Egypt is enjoying more attention for future sustainable development (Shaaban, 2010). This area has excellent locality for land reclamation and development projects. Water resources in the region are rainwater and groundwater Yousif et al., 2015). In this respect, Ali et al., 2007 indicated that, rainwater is the main source of water for cultivation, but the amount of water is insufficient as a result of the climatic changes. Therefore, groundwater may become the most reasonable complementary resource that is capable to supply or at least to share the resource in providing the area with the needed water (Shaaban, 2010 and Yousif, 2014).

The area under investigation occupies a portion of the Northwestern Coastal region of Egypt. It extends to about $140 \mathrm{~km}$. west Marsa Matrouh city. It is bounded by latitudes $31^{\circ} 26^{\prime}-31^{\circ} 31^{\prime} \mathrm{N}$ and longitudes $26^{\circ} 30^{\prime}$ $26^{\circ} 35^{\prime}$ E. The studied area occupies an area of 1600 feddan.

According to the profile depth, texture, salinity and degree of development Abd El-Rahman et al., (1984) reported that, northwestern coastal soils from the pedological point of view are a nine main soil associations were recognized. Its defined to thirteen soil families under the order Entisols and Aridisols and soils 
were found to be very much associated with the type and locations of the defined geomorphic units (Abd ElRahman et al., 1984).

On the other hand, El-Kady (1970) stated that, soils under study are low in their natural fertility levels due to the problem of phosphorous fixation, low nitrogen level and deficiency of zinc, iron and manganese. While, in other study Abd El-Rahman et al. (1986 and 1987) reported that, about $35-40 \%$ of the soils of northwestern coastal were marginal to moderate suitable for agricultural land utilization practices.

The present work carried out to identify the geomorphic units and landforms in the study area as well as, study the relationship between landforms and soils characteristics. In addition to classified the soils according to their taxonomy and land capability.

\section{MATERIAL AND METHODS}

\section{Physiographic feature of the studied area:}

The study area lies in the Mediterranean coastal zone west Matrouh city at northwestern coastal region of Egypt .It occupies an area of about 1600 feddan. It lies between latitudes $31^{\circ} 26^{\prime}-31^{\circ} 31^{\prime} \mathrm{N}$ and longitudes $26^{\circ} 30^{\prime}-26^{\circ} 35^{\prime} \mathrm{E}, 23$ soil profiles were chosen and examined in different locations covering the wadi to represent the different soil as seen in map (1).

The Digital Elevation Model (DEM) of the study area (Map..2) was extracted from the SRTM data (30 m resolution). DEM was employed to offer varieties of data that assist in produced landforms map, where the results indicated that elevations of the study area ranged between less $15 \mathrm{~m}$ to more than $60 \mathrm{~m}$ above Sea level.

\subsection{Climatologically:}

The region is considered one of the mildest over Mediterranean zone. Its climate is characterized by long hot dry summer and short cool rainy winter typical of sub-arid region, defined as "Arid Mediterranean". In general, monthly temperature varied between 14.4 and $26.8{ }^{\circ} \mathrm{C}$, wind speed averaged at $18.9 \mathrm{~km} / \mathrm{h}$., and the average annual rainfall ranged from 100 to $190 \mathrm{~mm}$ (DRC staff, 2010). According to the limits outlined by DRC staff (2010) soils are characterized by torric moisture and hyper thermic temperature regimes.

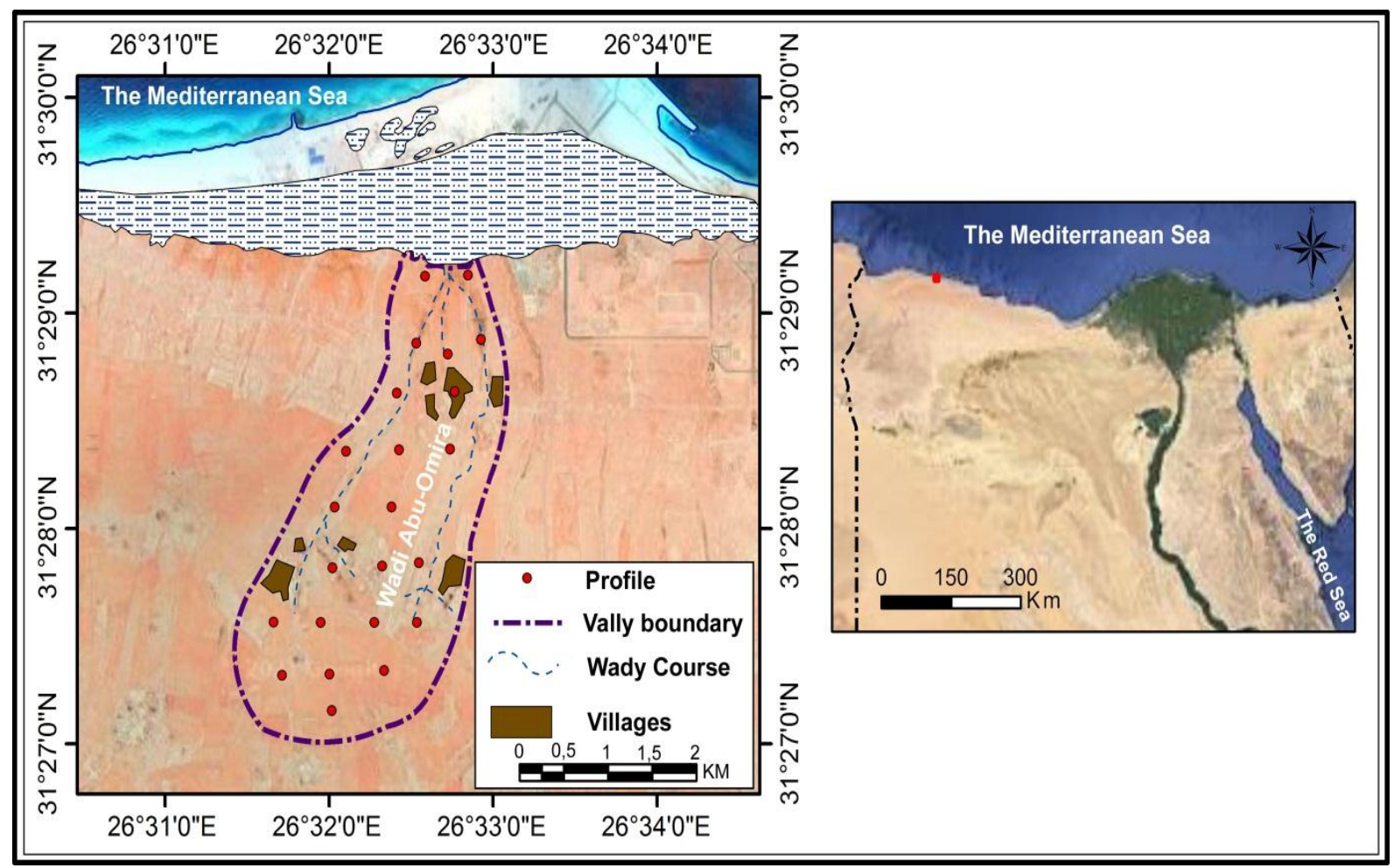

Map 1.Location of the study area 


\subsection{Geologically:}

The main rocks which contribute to the soil formation dominate by a sedimentary succession ranging from Tertiary period (Middle Miocene) to Quaternary. Middle Miocene sediments are widely spread in the table land. Quaternary deposits are differentiated into Pleistocene and Holocene formations. They have wide distribution and constitute the bulk of the coastal plain (El-Shazly et al., 1975). The area between the present shoreline and Libyan plateau is mostly constituted of calcareous Pliocene and Pleistocene formations and covered by recent deposits (Shata, 1971). The main source of irrigation water in the area is rainfall which insufficient. The amount of rainfall shows a steady decrease in the inland direction reaching about $50 \mathrm{~mm}$ at the southern limit of the catchment zone (FAO, 1970).

\section{Laboratory Analyses}

Twenty four soil profiles were collected representing the subsequent layers of the studied soil profiles according to FAO Guidelines (FAO, 2006). Forty four samples were air dried, crushed sieved through $2 \mathrm{~mm}$, the percentage of gravels was determined by volume. Then the fine earth $(<2 \mathrm{~mm})$ subjected to the following physical and chemical analyses were performed

\section{Chemical analyses}

- Soil reaction $(\mathrm{pH})$ was determined potentiometrically in the saturated soil paste using a Backman benchtype pH-meter, (Richards, 1954)

- Total salinity $\left(\mathrm{EC}_{\mathrm{e}}\right)$ was determined conductimterically in the soil saturation extract according to Richards (1954) and Nassem et al. (2008) .

- Organic carbon and organic matter contents were determined following the Walkley and Black titration method ( Jackson, 1973)

- Calcium carbonate was estimated volumetrically by means of Collins Calcimeter (Piper, 1950).

- Total $\mathrm{N}$ was determined by the microkjeldahl method as described by Jackson (1963).

- Available Iron, Manganese, Zinc, Phosphorus, and Potassium were determined according to the method illustrated by Soltanpour and Schwab (1977) and using Atomic absorption spectrophotometer, while phosphorus was determined by the techniques that was described by Olsen et al. (1954).

- Particle size distribution was done according to methods described by Kilmer and Alexander(1949)

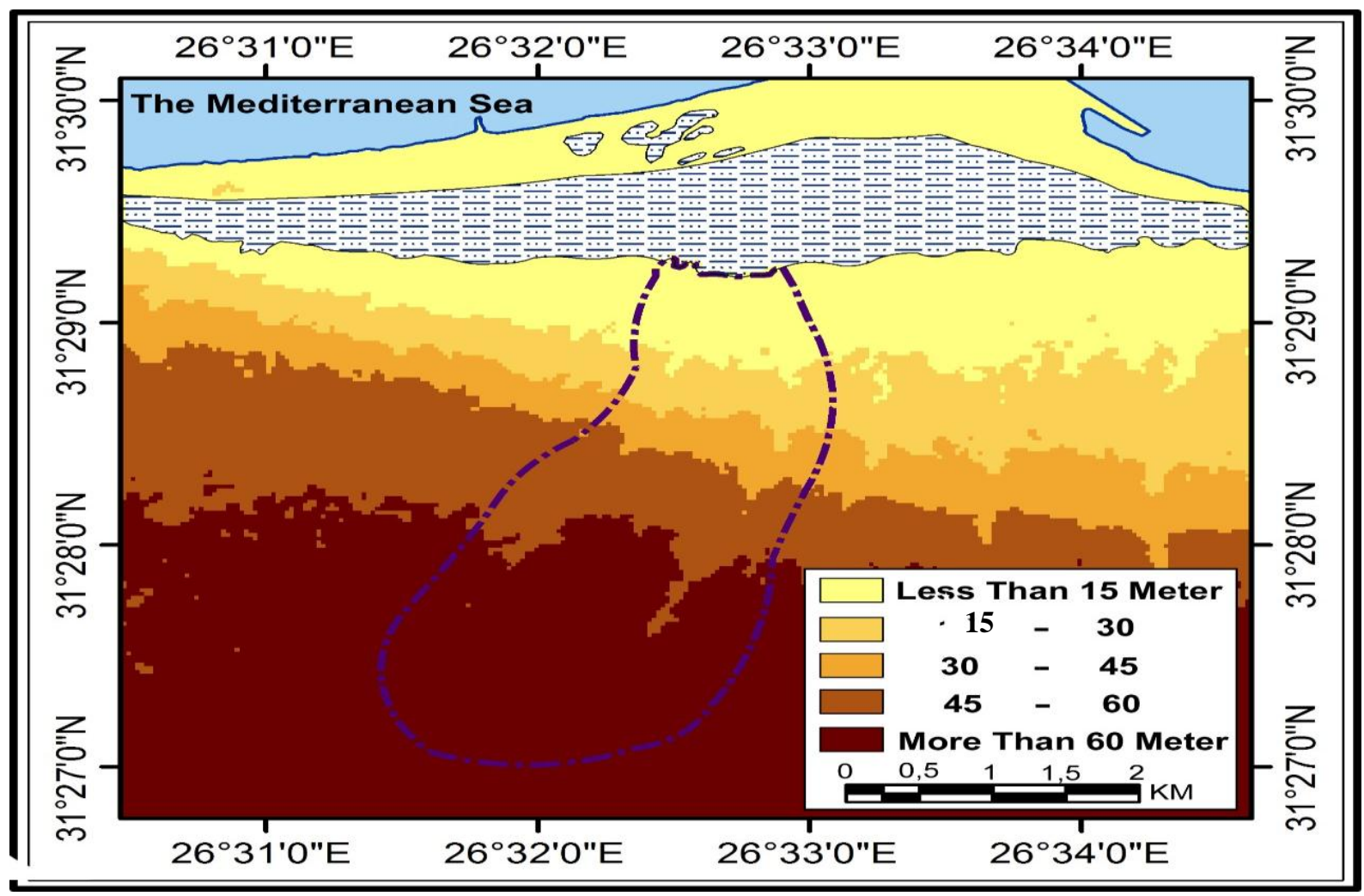

Map 2. Digital elevation model (DEM) 
Table 1. Classes of land suitability

\begin{tabular}{ll}
\hline Class & Soil limitations \\
S1 (slightly suitable) & Land units without or with only $3: 4$ slight limitations and no more than $1 / 2$ moderate limitations \\
S2 (moderately suitable) & Land units without or with only 2:3 slight limitations and no more than 2/3 moderate limitations \\
S3 (marginally suitable) & Land units with more than 3 moderate limitations and/or no more than severe limitations \\
N (unsuitable) & Land units with one or more severe or very severe limitations that exclude the use of the land. \\
\hline
\end{tabular}

\section{Land capability classification:}

Land capability assessment is based on a broader range of characteristics of soil properties i.e. slope angle, climate, flood and erosion risk. According to USDA, 1962 system classification structure namely capability classes which are the broadest category and includes eight classes from I to VIII.

\section{Land suitability}

Land suitability is classified according to FAO (2006) as shown in the Table (1) four degrees were used in this study S1 (Slightly suitable) S2 (moderately suitable), S3 (marginally suitable) and N1 (actually unsuitable).

The most limiting factors in the studied soils are topography of the terrain, profile depth, gravel, $\mathrm{CaCO}_{3}$, salinity index (EC), Exchangeable sodium ratio (ESP), available water (AW), while land suitability subclasses reflect kinds of limitations. The limitation were differentiated to five classes according to their expected hazards e.g., very low, low, moderate, severe and very severe.

\section{RESULTS AND DISCUSSION}

\section{Morphopedological, physical, chemical} characteristics and nutrients status of the studies soil:

Representative soil profiles taken from the geomorphic units of the investigated area (from north to south of Wadi Abu-Omira) which divided to three units; coastal plain, Piedmont plain and plateau. The most relevant some morphological, physical and chemical properties of studied soil profiles were set out. According to differences in profile depth, texture and topography, the results indicated that, three soil mapping units were differentiated (a) deep coarse to moderately coarse-textured soils profiles №.1,2,3 and 4, (B) shallow coarse to moderately coarse textured soils sometimes with moderately fine layers profiles №. $6,7,8,9,10,11,12,14,17,18$ and 19 , and (c) moderately deep coarse to moderately coarse textured soils profiles №. 5,12,1,16,20,21,22,23 are set out in Map (3).

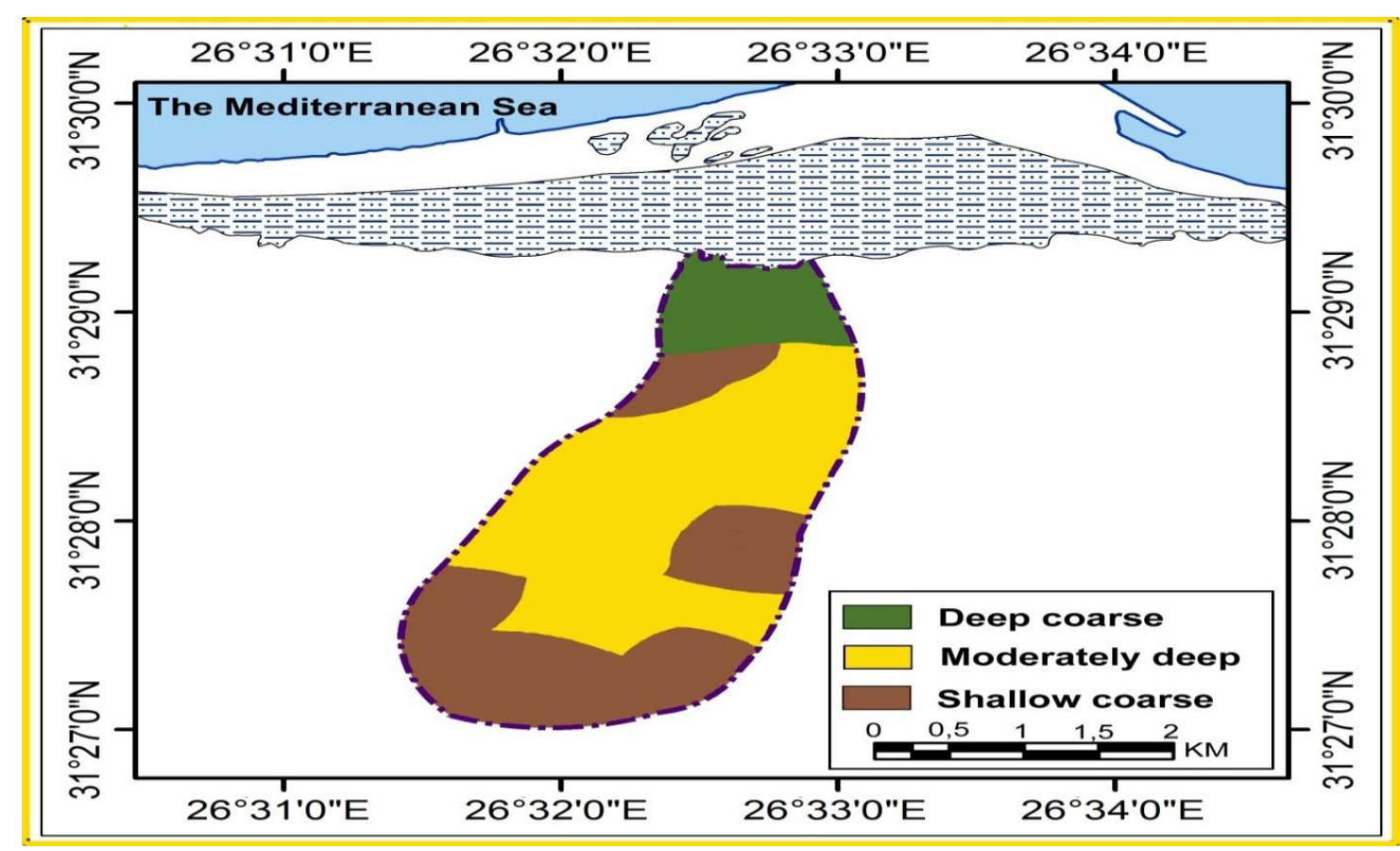

Map 3.Soil unit of study area 


\subsection{Coastal plain soil of Wadi Abu-Omira}

This unit occupies an area of about 191 feddan (12\% of the studied area), and it is represented by four soil profiles No. 1, 2, 3 and 4. Soil topography is almost flat $(0.5-2 \%)$ to gently undulating $(2-5 \%)$. Data in Table (2) indicate that, the soil is generally deep where the depth is ranging from $100-150 \mathrm{~cm}$. The color have a little change within the different layers of the profiles which indicate that, it may be inherited from the parent material and soil forming factors have a little effect in soil formation of this area.
The gravels content through the entire depth of the soil profile varies from 1.67 to $63.53 \%$, except profile No. 3 the gravel are concentrated in the subsurface layer (Table 3). Natural vegetation is absent or scattered with few to many green desert plants with low hummocks. Soil texture of the profiles is almost sandy to sandy loam in the surface layer. The field capacity and wilting point varies from 9.70 to $26.56 \%$ and 5.60 to $11.51 \%$ respectively, the available water varies through the subsequent layers between 4.0 to $15.05 \%$ and that is agrees well with soil texture (Table 3 ).

Table 2. Main morphological characteristics of the soils derived from coastal plain

\begin{tabular}{|c|c|c|c|c|c|c|c|c|c|}
\hline \multirow[t]{2}{*}{$\dot{z}^{01}$} & \multirow{2}{*}{ 言 } & \multirow{2}{*}{ 7.5 } & \multirow{2}{*}{ 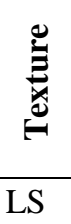 } & \multirow{2}{*}{ 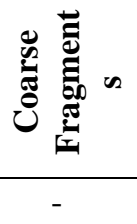 } & \multirow{2}{*}{ MA } & \multicolumn{2}{|c|}{ Consistence } & \multirow{2}{*}{$\begin{array}{l}\stackrel{n}{0} \\
\stackrel{0}{*}\end{array}$} & \multirow{2}{*}{ 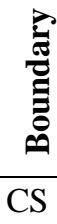 } \\
\hline & & & & & & SO & SST,NPL & & \\
\hline \multirow[t]{3}{*}{1} & $25-50$ & 7.5YR6/8 & $\mathrm{LS}$ & - & MA & SHA & SST,NPL & $\mathrm{FF}$ & CS \\
\hline & $50-125$ & 7.5YR6/8 & SL & - & MA & FR & SST,NPL & - & - \\
\hline & $0-25$ & 7.5YR6/6 & $\mathrm{LS}$ & - & MA & SHA & SST,NPL & $\mathrm{FF}$ & \\
\hline \multirow[t]{3}{*}{2} & $25-50$ & 7.5YR6/8 & $\mathrm{LS}$ & - & MA & HA & SST,NPL & FF & CS \\
\hline & $50-125$ & 7.5YR6/8 & SL & - & MA & FR & SST,NPL & - & - \\
\hline & $0-20$ & 7.5YR6/6 & $\mathrm{S}$ & CFM & MA & SHA & NST,NPL & FF & CS \\
\hline \multirow[t]{3}{*}{3} & $20-50$ & 7.5YR6/6 & LS & AFM & MA & HA & SST,NPL & FF & AS \\
\hline & $50-120$ & 7.5YR6/6 & $S$ & VF & MA & FR & NST,NPL & MFM & - \\
\hline & $0-40$ & 7.5YR6/6 & LS & VF & MA & SHA & SST,NPL & $\mathrm{FF}$ & CS \\
\hline \multirow[t]{2}{*}{4} & $40-60$ & 7.5YR6/6 & LS & VF & MA & HA & SST,NPL & $\mathrm{CM}$ & CS \\
\hline & $60-120$ & 7.5YR6/6 & SL & VF & MA & HA & SST,SPL & FM & - \\
\hline
\end{tabular}

Table 3. Some physical properties of the soils derived from coastal plain

\begin{tabular}{|c|c|c|c|c|c|c|c|c|c|}
\hline \multirow{2}{*}{$\begin{array}{c}\text { Profile } \\
\text { No. }\end{array}$} & \multirow{2}{*}{$\begin{array}{c}\text { Depth } \\
\text { (cm) }\end{array}$} & \multirow{2}{*}{ Gravel\% } & \multicolumn{3}{|c|}{ Particle size distribution \% } & \multirow{2}{*}{ Texture class } & \multicolumn{3}{|c|}{$\begin{array}{c}\text { Moisture } \\
\text { characteristics }\end{array}$} \\
\hline & & & Sand & Silt & Clay & & F.C & W.P & A.W \\
\hline \multirow{3}{*}{1} & $0-25$ & - & 84.38 & 7.22 & 8.4 & LS & 13.22 & 6.11 & 7.11 \\
\hline & $25-50$ & - & 82.92 & 7.89 & 9.19 & LS & 14.23 & 7.23 & 7.00 \\
\hline & $50-125$ & - & 78.15 & 10.75 & 11.1 & SL & 15.42 & 5.65 & 9.77 \\
\hline \multirow{3}{*}{2} & $0-25$ & - & 86.92 & 8.50 & 4.58 & LS & 15.52 & 8.02 & 7.5 \\
\hline & $25-50$ & - & 82.90 & 7.12 & 9.98 & LS & 9.70 & 5.60 & 4.00 \\
\hline & $50-125$ & - & 78.87 & 9.43 & 11.7 & SL & 10.93 & 6.36 & 4.57 \\
\hline \multirow{3}{*}{3} & $0-20$ & 9.30 & 89.82 & 5.18 & 5.0 & $\mathrm{~S}$ & 18.04 & 9.71 & 8.33 \\
\hline & $20-50$ & 63.53 & 84.97 & 12.2 & 2.83 & LS & 14.83 & 7.10 & 7.73 \\
\hline & $50-120$ & 1.67 & 89.30 & 6.37 & 4.33 & $\mathrm{~S}$ & 11.79 & 6.60 & 5.19 \\
\hline \multirow{3}{*}{4} & $0-40$ & 4.35 & 83.92 & 7.53 & 8.55 & LS & 20.53 & 6.23 & 14.30 \\
\hline & $40-60$ & 5.71 & 86.35 & 3.20 & 10.45 & LS & 17.20 & 8.96 & 8.24 \\
\hline & $60-120$ & 4.62 & 76.32 & 8.20 & 15.48 & SL & 26.56 & 11.51 & 15.05 \\
\hline
\end{tabular}


The contents of total carbonates indicated that, soils are moderately to extremely calcareous as calcium carbonate. Contents vary widely from 7.76 to $31.31 \%$, profile №. 1 recorded the highest contents (Table 4). In this respect, Abdou et al., (1983) and Abdel-Aal et al., (1990) found that, virgin calcareous soils had a relatively coarse texture with high content of carbonate mainly in the form of calcite, texture becomes finer and total $\mathrm{CaCO}_{3}$ level being minimized and associated with dominancy of dolomite due to particle dissolution of the lower calcic portion. The electrical conductivity values revealed that soils salinity varies widely from Non saline to slightly saline as indicated from its EC values which ranged from 0.202 to7.620 dS m$~^{-1}$ (Table 4). Cationic composition of soil extract is dominated by $\mathrm{Na}^{+}$ions followed by $\mathrm{Ca}^{++}$and $\mathrm{Mg}^{++}$then $\mathrm{K}^{+}$. Soluble anions are most dominated by $\mathrm{Cl}^{-}$followed by $\mathrm{So}_{4}{ }^{-}$then $\mathrm{HCO}_{3}$. These soils are classified two orders Aridisols and Entisols and two sub great groups level Typic Haplocalcids for profiles №. 1,2 and 3 and Typic Torripsamments for profile №. 4 and on family level recognized soil Taxonomic unit is coarse loamy, siliceous, hyper thermic, Typic Haplocalcids.

The data of the macro nutrients ( $\mathrm{N}, \mathrm{P}$ and $\mathrm{K})$ and organic matter in the study area which are given in Table (5) show that, the total nitrogen is varies from 41.3 to $63.1 \mathrm{mg} / \mathrm{kg}$, the lowest and the highest value are detected in the soil profiles №. 3\&4. Available phosphorus in the soils ranges from 0.91 to 11.78 $\mathrm{mg} / \mathrm{kg}$, while the available potassium ranges from 72.8 to $155.3 \mathrm{mg} / \mathrm{kg}$. The organic matter in coastal plain landform is concentrated on the surface and decreases with depth of profiles №. $1 \& 2$ and ranges between 0.115 to $0.377 \%$ (Table 5).

Regard to micro nutrients status, the available $\mathrm{Fe}$ in coastal plain fluctuates between 3.93 to $7.76 \mathrm{mg} / \mathrm{kg}$. In this respect, the lowest value detected in the subsurface layer of the soil profile №. 4 while the highest one is detected in the substratum of profile №.3. Available $\mathrm{Mn}$ in the soils under study ranges between 1.883 to $3.49 \mathrm{mg} / \mathrm{kg}$ while, available zinc concentration ranges from 1.387 to $1.929 \mathrm{mg} / \mathrm{kg}$ (Table, 5).

Table 4. Some chemical properties of the soils derived from coastal plain

\begin{tabular}{|c|c|c|c|c|c|c|c|c|c|c|c|}
\hline \multirow{2}{*}{$\begin{array}{c}\text { Profile } \\
\text { No. }\end{array}$} & \multirow{2}{*}{$\begin{array}{c}\text { Depth } \\
\text { (cm) }\end{array}$} & \multirow{2}{*}{$\begin{array}{c}\mathrm{CaCO}_{3} \\
\%\end{array}$} & \multirow{2}{*}{ pH } & \multirow{2}{*}{$\begin{array}{c}E c \\
\left(d S / m^{-1}\right)\end{array}$} & \multicolumn{4}{|c|}{ Cations (m.eq/L) } & \multicolumn{3}{|c|}{ Anion (m.eq/L) } \\
\hline & & & & & $\mathrm{Na}^{+}$ & $\mathbf{K}^{+}$ & $\mathrm{Ca}^{++}$ & $\mathrm{Mg}^{++}$ & $\mathrm{Cl}^{-}$ & $\mathrm{HCO}_{3}^{-}$ & $\mathrm{SO}_{4}^{--}$ \\
\hline \multirow{3}{*}{1} & $0-25$ & 10.76 & 7.97 & 2.660 & 18.3 & 0.62 & 4.87 & 2.92 & 18.86 & 1.72 & 6.08 \\
\hline & $25-50$ & 7.76 & 8.28 & 3.510 & 1.59 & 0.21 & 0.87 & 0.73 & 1.98 & 0.65 & 1.44 \\
\hline & $50-125$ & 31.31 & 7.69 & 7.620 & 61.7 & 0.78 & 14.5 & 11.2 & 69.36 & 2.3 & 16.33 \\
\hline \multirow{3}{*}{2} & $0-25$ & 10.67 & 8.00 & 0.597 & 3.72 & 0.25 & 1.25 & 0.75 & 3.95 & 1.25 & 0.77 \\
\hline & $25-50$ & 10.84 & 8.28 & 1.466 & 8.36 & 0.52 & 3.43 & 2.35 & 9.34 & 1.77 & 3.55 \\
\hline & $50-125$ & 27.30 & 8.28 & 2.89 & 20.2 & 1.13 & 4.93 & 2.74 & 20.48 & 2.75 & 5.57 \\
\hline \multirow{3}{*}{3} & $0-20$ & 10.41 & 8.09 & 0.347 & 1.76 & 0.27 & 0.89 & 0.55 & 1.87 & 0.85 & 0.75 \\
\hline & $20-50$ & 27.05 & 8.20 & 0.272 & 1.35 & 0.15 & 0.85 & 0.37 & 1.40 & 0.30 & 1.02 \\
\hline & $50-120$ & 11.77 & 8.37 & 0.202 & 1.01 & 0.09 & 0.53 & 0.39 & 1.10 & 0.25 & 0.67 \\
\hline \multirow{3}{*}{4} & $0-40$ & 13.48 & 7.98 & 0.566 & 3.55 & 0.25 & 1.11 & 0.75 & 3.72 & 1.23 & 0.71 \\
\hline & $40-60$ & 13.74 & 8.49 & 0.229 & 1.08 & 0.12 & 0.85 & 0.24 & 1.24 & 0.25 & 0.80 \\
\hline & $60-120$ & 14.33 & 8.42 & 0.268 & 1.21 & 0.15 & 0.83 & 0.49 & 1.34 & 0.32 & 1.02 \\
\hline
\end{tabular}

Table 5. Macro and micro nutrients and organic matter contents on the soils derived from coastal plain

\begin{tabular}{cccccccccc}
\hline \multirow{2}{*}{$\begin{array}{c}\text { Profile } \\
\text { No. }\end{array}$} & Depth & $\mathrm{N}$ & $\mathrm{P}$ & $\mathrm{K}$ & $\mathrm{Fe}$ & $\mathrm{Mn}$ & $\mathrm{Zn}$ & $\mathrm{Cu}$ & $\begin{array}{c}\text { Organic } \\
\text { matter } \\
(\%)\end{array}$ \\
\cline { 3 - 10 } & & & & & & & \\
1 & $25-50$ & 42.8 & 1.12 & 86.3 & 5.248 & 2.049 & 1.177 & 0.697 & 0.122 \\
& $0-25$ & 55.1 & 0.91 & 111.1 & 4.503 & 2.176 & 1.387 & 0.897 & 0.276 \\
2 & $25-50$ & 49.4 & 2.51 & 155.3 & 6.652 & 3.198 & 1.538 & 1.790 & 0.203 \\
& $0-20$ & 63.1 & 11.78 & 108.9 & 7.763 & 3.490 & 1.349 & 1.128 & 0.377 \\
3 & $20-50$ & 54.1 & 4.63 & 72.8 & 4.200 & 2.242 & 1.180 & 0.737 & 0.284 \\
4 & $0-40$ & 41.3 & 6.66 & 106.7 & 3.926 & 2.104 & 1.929 & 0.843 & 0.115 \\
\hline
\end{tabular}




\subsection{Soils of Piedmont plain}

This landform occupies an area of about 794 feddan (50\% of the studied area) which constitute the major part of the considered area. These soils are represented by soil profiles №. 5 to 15 (Table 6). Soils depths are varied from shallow in profiles №. 6,7,8,9,10,11,13 and 14 to, moderately deep in profiles №. 12 and 15 (Table $6)$.

Soil topography is gently undulating (2-5\%). Main soil of this unit are; a) shallow coarse to moderately coarse - textured soils, sometimes with moderately fine layers b) moderately deep coarse to moderately coarse textured soils.

Pedological features are limited and mostly observed as lime segregations on surface of soil profiles №.12 and 15. Color does not change much within the different layers of profiles as they are reddish yellow 7.5 YR6/6 at the dry condition and strong brown (7.5 YR5/6). Soil structure is massive in the surface layer, while, in subsurface gradually from slightly hard to hard. Stickiness and plasticity varied between non-sticky to slightly sticky and non-plastic to slightly plastic according to different texture (Table 6).

Land surface is covered with many varied size of gravel rock, limestone fragments, few shell fragments and desert pavement. Gravels content in their soil profiles ranges from 3.13 to $34.78 \%$ (Table 7). Distribution of natural vegetation ranges from none to common scattered desert shrub. Field capacity and wilting point range between $10.98-30.11 \%$, 2.74-
$13.22 \%$ respectively, available water varies throughout the subsequent layers between 4.11 and $16.89 \%$, reflecting the nature of soil texture (Table 7).

Data in Table (8) show that, salinity of the soil extract ranges from non-saline (EC $0.32 \mathrm{dS} \mathrm{m}^{-1}$ ) to moderately salty (EC $10.78 \mathrm{dS} \mathrm{m}^{-1}$ ), these soils are, relatively of low EC values, may be due to the continuous leaching by rainfall during Pleistocene age (Harga 1967). The $\mathrm{pH}$ values are slightly alkaline moderately alkaline $\mathrm{pH}$ (7.61-8.52) (Table 3). The soils of piedmont plain are calcareous. The content of calcium carbonates ranges from 10.24 to $24.74 \%$. The accumulation of calcium carbonates on some surface layers may be due to the natural of profiles location which near of the Marmarica plateau which contains a siliceous type of limestone and enriched with silica sand (El-Shalzly 1964 and Harga 1967).

The cationic composition of the soil extract is dominated by $\mathrm{Na}^{+}$followed by $\mathrm{Ca}^{++}$and, $\mathrm{Mg}^{++}$while $\mathrm{K}^{+}$ is the least in dominance. On the other hand the anionic composition is dominated by $\mathrm{Cl}^{-}$followed by $\mathrm{SO}_{4}^{--}$ while $\mathrm{HCO}_{3}{ }^{-}$is the least abundant soluble anions (Table 8). Soil of this unit are classified as subgreat group level classes were differentiated these are Typic Torripsaments for profile No. 5,6,7,8,12 and 15 and lithic Torripsaments for profiles №. 9,10,11,13 and 14 and Typic Haplocalcids for profile №. 15. On the family level they are classified as fine loam, siliceous, hyper Thermic, lithic Torripsamments and sandy skeletal, siliceous hyperthermic and Typic Haplocalcids.

Table 6. Main morphological characteristics of the soils derived from piedmont plain

\begin{tabular}{|c|c|c|c|c|c|c|c|c|c|}
\hline$\dot{z}^{i l}$ & $\frac{\overrightarrow{0}}{\overline{0}}$ & $\frac{\dot{\theta}}{\dot{\theta}}$ & 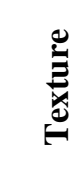 & 芯 & 窇 & & Consistence & 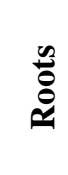 & 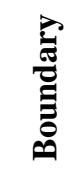 \\
\hline \multirow{2}{*}{5} & $0-25$ & 7.5YR6/6 & $S$ & CFM & MA & SHA & NST,NPL & FF & CS \\
\hline & $25-55$ & 7.5YR6/6 & $\mathrm{LS}$ & CFM & MA & HA & SST,NPL & - & $\mathrm{AS}$ \\
\hline 6 & $0-35$ & 7.5YR6/8 & $\mathrm{LS}$ & MFM & MA & SHA & SST,NPL & $\mathrm{FF}$ & AS \\
\hline 7 & $0-40$ & 7.5YR6/6 & $\mathrm{LS}$ & MFM & MA & SHA & SST,NPL & FF & AS \\
\hline 8 & $0-35$ & 7.5YR6/6 & S & MFM & MA & SHA & SST,SPL & $\mathrm{FF}$ & AS \\
\hline 9 & $0-35$ & 7.5YR6/6 & $\mathrm{LS}$ & CFM & MA & SHA & SST,NPL & FF & AS \\
\hline 10 & $0-30$ & $7.5 \mathrm{YR} / 6$ & $\mathrm{LS}$ & MFM & MA & SHA & SST,NPL & $\mathrm{FF}$ & AS \\
\hline 11 & $0-40$ & 7.5YR6/6 & SL & MF & MA & SHA & SST,SPL & FF & AS \\
\hline \multirow{2}{*}{12} & $0-30$ & 7.5YR6/6 & LS & $\mathrm{CF}$ & MA & SO & SST,NPL & $\mathrm{FF}$ & $\mathrm{CS}$ \\
\hline & $30-60$ & 7.5YR6/6 & SL & $\mathrm{MF}$ & MA & $\mathrm{HA}$ & SST,SPL & - & AS \\
\hline \multirow{2}{*}{13} & $0-20$ & 7.5 YR6/6 & SL & CFM & MA & SHA & SST,SPL & $\mathrm{FF}$ & AS \\
\hline & $20-40$ & 7.5YR6/6 & SCL & MFM & MA & SHA & SST,SPL & FF & AS \\
\hline \multirow{2}{*}{14} & $0-20$ & 7.5YR6/6 & SL & MFM & MA & $\mathrm{D}$ & SHASST,SPL & $\mathrm{FF}$ & $\mathrm{D}$ \\
\hline & $20-45$ & $7.5 \mathrm{YR} 7 / 6$ & SL & FFM & MA & AS & $\overline{\text { HASST,SPL }}$ & - & $\mathrm{AS}$ \\
\hline \multirow{2}{*}{15} & $0-30$ & $7.5 \mathrm{YR} 7 / 6$ & LS & CFM & MA & $\mathrm{CS}$ & SHASST,NPL & - & $\mathrm{CS}$ \\
\hline & $30-60$ & 5YR6/6 & SL & MFM & MA & AS & FISST,SPL & FF & $\mathrm{AS}$ \\
\hline
\end{tabular}


Table 7. Some physical properties of the soils derived from piedmont plain

\begin{tabular}{|c|c|c|c|c|c|c|c|c|c|}
\hline \multirow{2}{*}{$\begin{array}{c}\text { Profile } \\
\text { No. }\end{array}$} & \multirow{2}{*}{$\begin{array}{c}\text { Depth } \\
\text { (cm) }\end{array}$} & \multirow{2}{*}{ Gravel\% } & \multicolumn{3}{|c|}{$\begin{array}{c}\text { Particle size } \\
\text { distribution \% }\end{array}$} & \multirow{2}{*}{$\begin{array}{l}\text { Texture } \\
\text { class }\end{array}$} & \multicolumn{3}{|c|}{ Moisture characteristics } \\
\hline & & & Sand & Silt & Clay & & F.C & W.C & A.W \\
\hline \multirow{2}{*}{5} & $0-25$ & 6.60 & 89.55 & 4.25 & 6.20 & $\mathrm{~S}$ & 17.68 & 5.16 & 12.52 \\
\hline & $25-55$ & 9.20 & 81.05 & 12.2 & 3.70 & LS & 11.39 & 6.17 & 5.22 \\
\hline 6 & $0-35$ & 15.61 & 85.97 & 10.3 & 3.58 & LS & 10.98 & 6.87 & 4.11 \\
\hline 7 & $0-40$ & 19.23 & 84.12 & 12.3 & 8.18 & LS & 18.59 & 5.78 & 12.81 \\
\hline 8 & $0-35$ & 23.81 & 71.22 & 20.6 & 2.25 & SL & 22.27 & 8.92 & 13.53 \\
\hline 9 & $0-35$ & 9.09 & 83.30 & 14.5 & 6.10 & LS & 14.32 & 8.89 & 5.43 \\
\hline 10 & $0-30$ & 31.25 & 87.75 & 6.15 & 6.20 & LS & 11.80 & 2.74 & 9.06 \\
\hline 11 & $0-40$ & 30.43 & 73.17 & 20.6 & 10.12 & SL & 15.26 & 6.28 & 8.98 \\
\hline \multirow{2}{*}{12} & $0-30$ & 5.88 & 81.18 & 8.7 & 13.90 & LS & 11.98 & 6.42 & 5.56 \\
\hline & $30-60$ & 20.0 & 69.49 & 16.6 & 10.60 & SL & 24.30 & 6.67 & 17.63 \\
\hline \multirow{2}{*}{13} & $0-20$ & 8.13 & 74.70 & 14.7 & 24.55 & SL & 17.05 & 8.09 & 8.96 \\
\hline & $20-40$ & 28.57 & 50.45 & 25.0 & 12.89 & S.C.L & 30.11 & 13.22 & 16.89 \\
\hline \multirow{2}{*}{14} & $0-20$ & 26.67 & 70.61 & 16.5 & 17.10 & SL & 18.65 & 6.30 & 12.35 \\
\hline & $20-45$ & 3.13 & 60.44 & 22.5 & 8.56 & SL & 16.70 & 7.67 & 9.03 \\
\hline \multirow{2}{*}{15} & $0-30$ & 11.63 & 82.14 & 9.30 & 14.30 & LS & 18.52 & 6.19 & 12.33 \\
\hline & $30-60$ & 34.78 & 68.46 & 17.2 & 14.32 & SL & 16.78 & 7.57 & 9.21 \\
\hline
\end{tabular}

Table 8. Some chemical properties of the soils derived from piedmont plain

\begin{tabular}{|c|c|c|c|c|c|c|c|c|c|c|c|}
\hline \multirow{2}{*}{$\begin{array}{c}\text { Profile } \\
\text { No. }\end{array}$} & \multirow{2}{*}{$\begin{array}{c}\text { Depth } \\
\text { (cm) }\end{array}$} & \multirow{2}{*}{$\begin{array}{c}\mathrm{CaCO}_{3} \\
\%\end{array}$} & \multirow{2}{*}{ pH } & \multirow{2}{*}{$\begin{array}{c}\text { Ec } \\
\left(\mathrm{dS} / \mathbf{m}^{-1}\right)\end{array}$} & \multicolumn{4}{|c|}{ Cations (m.eq/L) } & \multicolumn{3}{|c|}{ Anion (m.eq/L) } \\
\hline & & & & & $\mathbf{N a}^{+}$ & $\mathbf{K}^{+}$ & $\mathrm{Ca}^{++}$ & $\mathbf{M g}^{++}$ & $\mathrm{Cl}^{-}$ & $\mathrm{CO}_{3}$ & $\mathrm{HCO}_{3}$ \\
\hline \multirow{2}{*}{5} & $0-25$ & 11.01 & 8.48 & 0.320 & 1.65 & 0.15 & 0.87 & 0.53 & 1.71 & 0.0 & 0.45 \\
\hline & $25-55$ & 12.63 & 8.48 & 0.412 & 2.50 & 0.23 & 0.84 & 0.55 & 2.90 & 0.0 & 0.55 \\
\hline 6 & $0-35$ & 10.24 & 8.52 & 0.438 & 2.70 & 0.25 & 0.79 & 0.55 & 2.90 & 0.0 & 0.55 \\
\hline 7 & $0-40$ & 12.88 & 8.11 & 0.352 & 1.57 & 0.15 & 0.97 & 0.83 & 1.63 & 0.0 & 0.55 \\
\hline 8 & $0-35$ & 21.67 & 8.14 & 2.970 & 16.68 & 1.22 & 7.35 & 3.45 & 17.95 & 0.0 & 4.85 \\
\hline 9 & $0-35$ & 14.33 & 8.34 & 0.612 & 3.85 & 0.36 & 1.12 & 0.79 & 4.40 & 0.0 & 0.70 \\
\hline 10 & $0-30$ & 13.52 & 8.20 & 0.296 & 1.25 & 0.15 & 0.87 & 0.69 & 1.64 & 0.0 & 0.32 \\
\hline 11 & $0-40$ & 22.18 & 7.73 & 3.24 & 36.80 & 1.70 & 7.28 & 3.24 & 36.80 & 0.0 & 2.65 \\
\hline \multirow{2}{*}{12} & $0-30$ & 11.26 & 8.15 & 0.429 & 2.62 & 0.25 & 0.79 & 0.63 & 2.97 & 0.0 & 0.55 \\
\hline & $30-60$ & 12.12 & 8.67 & 0.237 & 1.05 & 0.12 & 0.96 & 0.24 & 1.18 & 0.0 & 0.23 \\
\hline \multirow{2}{*}{13} & $0-20$ & 16.98 & 7.97 & 0.514 & 2.55 & 0.14 & 1.65 & 0.80 & 3.46 & 0.0 & 0.85 \\
\hline & $20-40$ & 14.33 & 8.07 & 0.313 & 1.41 & 0.13 & 1.12 & 0.47 & 1.50 & 0.0 & 0.79 \\
\hline \multirow{2}{*}{14} & $0-20$ & 10.41 & 8.29 & 3.340 & 20.79 & 1.01 & 7.09 & 4.51 & 21.30 & 0.0 & 2.43 \\
\hline & $20-45$ & 24.74 & 8.04 & 10.780 & 106.52 & 0.81 & 20.76 & 4.51 & 21.30 & 2.55 & 2.43 \\
\hline \multirow{2}{*}{15} & $0-30$ & 22.78 & 7.83 & 0.812 & 2.37 & 0.35 & 3.44 & 1.96 & 2.69 & 0.0 & 2.55 \\
\hline & $30-60$ & 15.44 & 7.45 & 0.235 & 1.06 & 0.13 & 0.90 & 0.27 & 1.12 & 0.0 & 2.25 \\
\hline
\end{tabular}

The obtained data from Table (9) showed that, the content of total $\mathrm{N}$ ranges from 36.7 to $71.2 \mathrm{mg} / \mathrm{kg}$, the highest value detected in the soil profile №. 5 , while the available phosphorus ranges from 0.85 to $12.11 \mathrm{mg} / \mathrm{kg}$ which detected in soils profiles No. 6 and14 respectively. However, available potassium in this soils range from 68.0 to $166.9 \mathrm{mg} / \mathrm{kg}$.

The content of organic matter in piedmont plain in different soils depths is generally very low, being in the range of 0.095 to $0.0513 \%$. This may be due to the lake of natural vegetation in the upper layers. 
Table 9. Macro and micro nutrients and organic matter contents on the soils derived from piedmont plain

\begin{tabular}{|c|c|c|c|c|c|c|c|c|c|}
\hline \multirow{2}{*}{$\begin{array}{c}\text { Profile } \\
\text { NO }\end{array}$} & \multirow{2}{*}{ Depth } & \multicolumn{7}{|c|}{ Available nutrients, mg/kg } & \multirow{2}{*}{ OM\% } \\
\hline & & $\mathbf{N}$ & $\mathbf{P}$ & $\mathbf{K}$ & $\mathbf{F e}$ & Mn & $\mathbf{Z n}$ & $\mathbf{C u}$ & \\
\hline 5 & $0-25$ & 71.2 & 3.88 & 88.8 & 4.314 & 2.286 & 1.402 & 0.810 & 0.425 \\
\hline 6 & $0-35$ & 38.1 & 0.85 & 83.6 & 3.398 & 2.898 & 0.691 & 0.455 & 0.162 \\
\hline 7 & $0-40$ & 44.6 & 2.90 & 123.0 & 3.394 & 1.810 & 0.661 & 0.346 & 0.219 \\
\hline 8 & $0-35$ & 68.8 & 1.34 & 71.6 & 1.691 & 2.844 & 0.822 & 0.519 & 0.513 \\
\hline 9 & $0-35$ & 52.6 & 1.63 & 125.0 & 2.904 & 1.626 & 0.622 & 0.392 & 0.200 \\
\hline 10 & $0-30$ & 55.9 & 1.89 & 117.6 & 5.334 & 3.419 & 0.652 & 0.438 & 0.238 \\
\hline 11 & $0-40$ & 41.1 & 1.73 & 93.3 & 4.222 & 1.920 & 0.554 & 0.412 & 0.133 \\
\hline 12 & $0-30$ & 58.7 & 1.11 & 98.0 & 5.669 & 2.452 & 1.354 & 0.634 & 0.143 \\
\hline \multirow{2}{*}{13} & $0-20$ & 47.7 & 12.11 & 166.9 & 3.082 & 2.838 & 0.542 & 0.309 & 0.266 \\
\hline & $20-40$ & 27.8 & 1.50 & 111.3 & 4.646 & 3.951 & 1.268 & 0.461 & 0.095 \\
\hline \multirow{2}{*}{14} & $0-20$ & 36.7 & 2.61 & 124.6 & 3.705 & 2.388 & 0.725 & 0.298 & 0.228 \\
\hline & $20-45$ & 36.8 & 1.50 & 84.7 & 3.904 & 2.759 & 0.666 & 0.375 & 0.181 \\
\hline 15 & $0-30$ & 59.9 & 2.06 & 68.0 & 3.625 & 2.085 & 0.910 & 0.596 & 0.330 \\
\hline
\end{tabular}

In case of micro nutrients status date in Table (9) illustrated that, the content of available $\mathrm{Fe}$ ranges from 1.691 to $5.334 \mathrm{mg} / \mathrm{kg}$ which recorded in profiles №. 8 \&10. The available $\mathrm{Mn}$ fluctuate between 1.626 to $3.951 \mathrm{mg} / \mathrm{kg}$, the lowest value is detected in the surface layer of the soil profile No.9. However the content of available $\mathrm{Zn}$ in the piedmont plain fluctuates between 0.542 to $1.402 \mathrm{mg} / \mathrm{kg}$. The content of available $\mathrm{Cu}$ ranges between 0.81 to $0.634 \mathrm{mg} / \mathrm{kg}$, the highest value is detected in the surface layer of the soil profile No. 5, while the lowest value is detected in the surface layer of the soil profile №. 12 (Table, 9).

\subsection{Soil of structural plateau}

The geomorphic unit occupies an area about 615 feddan (38\% of the studies area) and it is represented by eight soil profiles (Table 10). The structure plateau occupies the southern portion of the studied area which characterized by uniform with general slope towards the north. The mean elevation is more than 100 above the sea level. Soil topography is almost flat $(0.5-2 \%)$ to gently undulating (2-5\%). Soil texture varied from loam sand to loam profiles and depth are varied from shallow in profiles №. $16,17,18$ and 19 to moderately deep in profiles №. $20,21,22$ and 23.

Table 10. Main morphological characteristics of the soils derived from plateau

\begin{tabular}{|c|c|c|c|c|c|c|c|c|}
\hline$\dot{z}^{i}$ & 䓂 & $\frac{\grave{o}}{\dot{\theta}}$ & 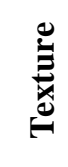 & 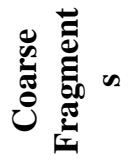 & 苞 & Consistence & $\underset{\tilde{0}}{\tilde{\theta}}$ & $\stackrel{\vec{E}}{0}$ \\
\hline \multirow{2}{*}{16} & $0-30$ & 7.5 YR6/6 & LS & FFM & MA & $\begin{array}{ll}\text { SHA } & \text { SST,NPL }\end{array}$ & FF & $\mathrm{D}$ \\
\hline & $30-55$ & 7.5YR6/6 & SL & MFM & MA & VHA SST,SPL & $\mathrm{FF}$ & AS \\
\hline \multirow{2}{*}{17} & $0-20$ & $7.5 \mathrm{YR} 6 / 6$ & SL & MFM & MA & $\overline{\text { SHA SST,SPL }}$ & FF & AS \\
\hline & $20-40$ & $7.5 Y R 6 / 6$ & $\mathrm{~L}$ & $\mathrm{CFM}$ & MA & VHA ST,PL & $\mathrm{FF}$ & AS \\
\hline \multirow{2}{*}{18} & $0-30$ & 7.5 YR6/6 & SL & FFM & MA & HA SST,SPL & VF & CS \\
\hline & $30-50$ & 7.5YR6/6 & SL & MFM & MA & HA SST,SPL & VF & AS \\
\hline \multirow{2}{*}{19} & $0-20$ & 7.5YR6/6 & SL & $\mathrm{CFM}$ & MA & HA SST,SPL & FFM & $\mathrm{CS}$ \\
\hline & $20-40$ & 7.5 YR6/6 & $\mathrm{L}$ & CFM & MA & HA ST,PL & $\mathrm{FF}$ & AS \\
\hline \multirow{2}{*}{20} & $0-20$ & 7.5YR6/6 & SL & CFM & MA & SHA SST,SPL & $\mathrm{FF}$ & $\mathrm{CS}$ \\
\hline & $20-55$ & 7.5YR6/6 & $\mathrm{LS}$ & MFM & MA & $\begin{array}{l}\text { HA SST,NPL } \\
\end{array}$ & FF & AS \\
\hline \multirow{2}{*}{21} & $0-20$ & $7.5 \mathrm{YR} 6 / 6$ & SL & MFM & MA & $\overline{\text { SHA SST,SPL }}$ & $\mathrm{FF}$ & $\mathrm{CS}$ \\
\hline & $20-55$ & 7.5YR7/6 & SL & MFM & MA & $\overline{\text { HA SST,SPL }}$ & $\mathrm{FF}$ & AS \\
\hline \multirow{2}{*}{22} & $0-40$ & 7.5YR6/6 & LS & CFM & MA & $\overline{\text { HA SST,NPL }}$ & $\mathrm{FF}$ & $\mathrm{CS}$ \\
\hline & $40-90$ & $7.5 Y R 7 / 6$ & SL & CFM & MA & $\overline{\text { HA SST,SPL }}$ & FF & AS \\
\hline \multirow{2}{*}{23} & $0-30$ & $7.5 \mathrm{YR} 6 / 6$ & SL & CFM & MA & $\overline{\text { SHA SST,SPL }}$ & FF & CS \\
\hline & $30-90$ & $7.5 \mathrm{YR} 7 / 6$ & SL & CFM & MA & $\begin{array}{l}\text { HA SST,SPL } \\
\end{array}$ & $\mathrm{FF}$ & AS \\
\hline
\end{tabular}


The land surface is covered with gravels and limestone fragments. The gravels content through the entire depth of soil profile ranges from 8.0 to $35 \%$. Natural vegetation is absent or scattered with few to common green deserts shrubs. While, the field capacity and wilting point were 11.34 to 26.26 and 2.74 to $11.93 \%$ respectively. Moreover, the calculated available water ranges from 4.991 to $17.50 \%$ (Table 11).

Electrical conductivity (EC) values of the soil saturation extract vary widely from 0.276 to $6.760 \mathrm{dS}$ $\mathrm{m}^{-1}$, these soil are non-saline to slightly saline. The soils reaction varies from neutral to strongly alkaline $(\mathrm{pH}$ values range from 7.19 to 8.66). The cationic composition of the soils are generally dominated by $\mathrm{Na}$ followed by $\mathrm{Ca}^{++}, \mathrm{Mg}^{++}$and $\mathrm{K}^{+}$and anionic compositions are generally dominated by $\mathrm{Cl}^{-}$and $\mathrm{SO}_{4}^{--}$ then $\mathrm{HCO}_{3}{ }^{-}$(Table12).

Soil were classified into three sub great group level classes were differentiated these are Typic Torripsamments for profile №.16, 19, 20, 21 and lithic Torrpsamments for profile №.17 and 18 and Tipic Haplocalcids for profile №. 22 and 23 DRC staff (2010), family levels could be defined sandy skeletal siliceous hyperthermic Typic Haplocalcids

The analytical data which obtained from Table (12) show that, calcium carbonates fluctuates from 12.2 to
$32.51 \%$ through the entire depth of soil profile. On the other hand there are no big different in the lime content of the successive horizons.

The presented data in Table (13) showed that, the soil of structural plateau have moderate levels of a total nitrogen it ranges between 31.2 and $63.3 \mathrm{mg} / \mathrm{kg}$, the lowest value was detected in soil profile №.18 while the highest value was detected in soil profile №.22.Available phosphorus recorded low values compared to the total nitrogen; it ranges from 1.18 to $8.32 \mathrm{mg} / \mathrm{kg}$. Regard to the available potassium in the soil of structural plateau, it ranges from 60.2 to 151.4 $\mathrm{mg} / \mathrm{kg}$. However, the organic matter ranges between 0.19 to $0.366 \mathrm{mg} / \mathrm{kg}$, the lowest value was detected in soil profile №.17 while the highest value was detected in soil profile №.23 (Table 13).

Regard to micro nutrients status data in Table (9) illustrated that, the content of available Fe ranges from 1.981 to $6.379 \mathrm{mg} / \mathrm{kg}$, soil profile №.19 recorded the lowest value, while the highest value was detected in soil profile No.20. The content of available Mn as well as both of $\mathrm{Zn}$ and $\mathrm{Cu}$ doesn't give a big difference between soil profile and their values ranged between 1.117 and $2.980 \mathrm{mg} / \mathrm{kg}$ for $\mathrm{Mn}, 0.664$ and 1.546 for $\mathrm{Zn}$ and 0.166 and 0.366 for $\mathrm{Cu}$.

Table 11. Some physical properties of the soils derived from plateau

\begin{tabular}{|c|c|c|c|c|c|c|c|c|c|}
\hline \multirow{2}{*}{$\begin{array}{c}\text { Profile } \\
\text { No.. }\end{array}$} & \multirow{2}{*}{$\begin{array}{c}\text { Depth } \\
\text { (cm) }\end{array}$} & \multirow{2}{*}{ Gravel\% } & \multicolumn{3}{|c|}{ Particle size distribution \% } & \multirow{2}{*}{ Texture class } & \multicolumn{3}{|c|}{ Moisture characteristic } \\
\hline & & & Sand & Silt & Clay & & F.C & W.P & A.W \\
\hline \multirow{2}{*}{16} & $0-30$ & 8.00 & 13.4 & 18.0 & 8.70 & LS & 11.80 & 2.74 & 9.06 \\
\hline & $30-55$ & 33.33 & 71.6 & 16.2 & 12.25 & SL & 13.67 & 5.10 & 8.57 \\
\hline \multirow{2}{*}{17} & $0-20$ & 19.44 & 72.7 & 17.2 & 10.13 & SL & 17.96 & 8.05 & 9.91 \\
\hline & $20-40$ & 8.70 & 44.2 & 40.9 & 25.15 & $\mathrm{~L}$ & 25.21 & 11.60 & 13.61 \\
\hline \multirow{2}{*}{18} & $0-30$ & 4.55 & 72.0 & 17.6 & 10.45 & SL & 16.92 & 8.28 & 8.64 \\
\hline & $30-50$ & 23.08 & 79.1 & 13.3 & 7.55 & SL & 18.65 & 6.30 & 12.35 \\
\hline \multirow{2}{*}{19} & $0-20$ & 8.00 & 64.2 & 18.1 & 17.65 & SL & 16.31 & 7.43 & 8.88 \\
\hline & $20-40$ & 5.56 & 47.3 & 30.2 & 22.50 & $\mathrm{~L}$ & 24.15 & 10.62 & 13.52 \\
\hline \multirow{2}{*}{20} & $0-20$ & 20.45 & 75.0 & 18.3 & 6.73 & SL & 14.44 & 5.14 & 9.30 \\
\hline & $20-55$ & 35.00 & 71.1 & 24.0 & 4.93 & LS & 26.26 & 8.78 & 17.50 \\
\hline \multirow{2}{*}{21} & $0-20$ & 25.00 & 80.4 & 11.6 & 8.03 & SL & 13.93 & 4.99 & 8.94 \\
\hline & $22-55$ & 28.57 & 74.0 & 21.9 & 4.13 & SL & 22.27 & 8.92 & 13.35 \\
\hline \multirow{2}{*}{22} & $0-40$ & 8.00 & 73.2 & 21.1 & 5.70 & LS & 11.34 & 6.17 & 5.22 \\
\hline & $40-90$ & 12.50 & 65.6 & 20.5 & 13.88 & SL & 26.36 & 11.93 & 14.45 \\
\hline \multirow{2}{*}{23} & $0-30$ & 13.33 & 73.8 & 15.4 & 10.85 & SL & 11.53 & 6.53 & 5.00 \\
\hline & $30-90$ & 12.50 & 65.4 & 19.9 & 14.68 & SL & 11.50 & 6.51 & 4.99 \\
\hline
\end{tabular}


Table 12. Some chemical properties of the soils derived from plateau

\begin{tabular}{|c|c|c|c|c|c|c|c|c|c|c|c|}
\hline \multirow{2}{*}{$\begin{array}{c}\text { Profile } \\
\text { No. }\end{array}$} & \multirow{2}{*}{$\begin{array}{c}\text { Depth } \\
\text { (cm) }\end{array}$} & \multirow{2}{*}{$\begin{array}{c}\mathrm{CaCO}_{3} \\
\%\end{array}$} & \multirow{2}{*}{ pH } & \multirow{2}{*}{$\begin{array}{c}\text { Ec } \\
\left(\mathrm{dS} / \mathbf{m}^{-1}\right)\end{array}$} & \multicolumn{4}{|c|}{ Cations (m.eq/L) } & \multicolumn{3}{|c|}{ Anion (m.eq/L) } \\
\hline & & & & & $\mathbf{N a}^{+}$ & $\mathbf{K}^{+}$ & $\mathbf{C a}^{++}$ & $\mathbf{M g}^{++}$ & $\mathrm{Cl}^{-}$ & $\mathrm{HCO}_{3}^{-}$ & $\mathrm{SO}_{4}^{--}$ \\
\hline \multirow{2}{*}{16} & $0-30$ & 15.61 & 7.19 & 0.457 & 1.80 & 0.25 & 1.84 & 0.68 & 2.36 & 0.60 & 1.61 \\
\hline & $30-55$ & 18.6 & 8.07 & 1.049 & 3.69 & 0.35 & 4.51 & 1.94 & 4.06 & 1.85 & 4.58 \\
\hline \multirow{2}{*}{17} & $0-20$ & 15.7 & 7.53 & 0.909 & 3.55 & 0.73 & 33.38 & 1.43 & 3.99 & 2.30 & 1.78 \\
\hline & $20-40$ & 15.7 & 8.45 & 0.888 & 3.89 & 0.55 & 3.49 & 0.95 & 3.98 & 1.66 & 2.24 \\
\hline \multirow{2}{*}{18} & $0-30$ & 16.89 & 7.76 & 6.760 & 66.1 & 1.01 & 8.40 & 4.65 & 65.8 & 4.55 & 7.95 \\
\hline & $30-50$ & 20.9 & 8.03 & 6.230 & 61.1 & 0.95 & 8.55 & 4.46 & 60.75 & 3.50 & 8.05 \\
\hline \multirow{2}{*}{19} & $0-20$ & 13.57 & 8.30 & 0.436 & 1.86 & 0.38 & 1.26 & 0.86 & 1.95 & 0.82 & 0.39 \\
\hline & $20-40$ & 14.85 & 8.43 & 0.276 & 1.25 & 0.15 & 0.86 & 0.50 & 1.40 & 0.35 & 1.01 \\
\hline \multirow{2}{*}{20} & $0-20$ & 13.91 & 8.23 & 1.067 & 5.63 & 0.45 & 3.06 & 1.53 & 6.12 & 1.79 & 2.77 \\
\hline & $20-55$ & 17.41 & 8.20 & 2.850 & 20.1 & 1.13 & 4.93 & 2.74 & 20.48 & 2.70 & 5.67 \\
\hline \multirow{2}{*}{21} & $0-20$ & 14.08 & 8.37 & 0.713 & 4.54 & 0.45 & 1.25 & 0.85 & 4.72 & 1.25 & 1.11 \\
\hline & $22-55$ & 15.7 & 7.90 & 1.376 & 9.05 & 0.25 & 3.30 & 1.52 & 9.60 & 1.90 & 2.57 \\
\hline \multirow{2}{*}{22} & $0-40$ & 12.2 & 8.39 & 0.788 & 5.55 & 0.08 & 1.89 & 1.26 & 5.89 & 0.63 & 2.54 \\
\hline & $40-90$ & 32.17 & 8.55 & 0.698 & 4.16 & 0.45 & 1.43 & 0.94 & 4.99 & 0.51 & 1.48 \\
\hline \multirow{2}{*}{23} & $0-30$ & 13.05 & 8.66 & 0.314 & 1.39 & 0.15 & 0.87 & 0.73 & 1.50 & 0.53 & 1.11 \\
\hline & $30-90$ & 32.51 & 8.68 & 0.748 & 4.45 & 0.39 & 2.72 & 0.92 & 4.72 & 1.20 & 1.56 \\
\hline
\end{tabular}

Table 13. Macro and micro nutrients and organic matter contents on the soils derived from structural plateau

\begin{tabular}{|c|c|c|c|c|c|c|c|c|c|}
\hline \multirow{2}{*}{$\begin{array}{c}\text { Profile } \\
\text { NO }\end{array}$} & \multirow{2}{*}{ Depth } & \multicolumn{7}{|c|}{ Available nutrients, $\mathrm{mg} / \mathrm{kg}$} & \multirow{2}{*}{ OM\% } \\
\hline & & $\mathrm{N}$ & $\mathrm{P}$ & $\mathrm{K}$ & $\mathrm{Fe}$ & $\mathrm{Mn}$ & $\mathrm{Zn}$ & $\mathrm{Cu}$ & \\
\hline 16 & $0-30$ & 74.6 & 1.89 & 143.0 & 5.569 & 2.400 & 1.410 & 0.849 & 0.341 \\
\hline \multirow{2}{*}{17} & $0-20$ & 49.0 & 2.28 & 151.4 & 5.062 & 2.942 & 0.822 & 0.469 & 0.190 \\
\hline & $20-40$ & 33.9 & 2.12 & 107.9 & 2.544 & 2.938 & 1.152 & 0.600 & 0.200 \\
\hline 18 & $0-30$ & 31.2 & 3.36 & 150.4 & 3.292 & 1.794 & 0.721 & 0.450 & 0.257 \\
\hline \multirow{2}{*}{19} & $0-20$ & 41.4 & 1.44 & 131.1 & 1.981 & 2.809 & 0.688 & 0.501 & 0.191 \\
\hline & $20-40$ & 34.4 & 7.04 & 140.0 & 2.482 & 2.318 & 0.664 & 0.348 & 0.228 \\
\hline \multirow{2}{*}{20} & $0-20$ & 54.5 & 8.32 & 140.2 & 4.699 & 2.545 & 1.309 & 0.656 & 0.264 \\
\hline & $20-55$ & 42.7 & 2.36 & 91.3 & 6.379 & 2.183 & 0.903 & 0.554 & 0.225 \\
\hline \multirow{2}{*}{21} & $0-20$ & 50.0 & 3.07 & 147.9 & 3.497 & 2.980 & 1.546 & 0.751 & 0.297 \\
\hline & $20-55$ & 51.9 & 2.19 & 60.2 & 2.724 & 1.117 & 1.314 & 0.682 & 0.166 \\
\hline 22 & $0-40$ & 63.3 & 2.77 & 81.8 & 5.116 & 2.645 & 1.201 & 0.551 & 0.297 \\
\hline 23 & $0-30$ & 56.8 & 1.18 & 128.8 & 4.124 & 2.057 & 1.435 & 0.615 & 0.366 \\
\hline
\end{tabular}

\section{Land capability}

Data in Map (4) showed that, soils of the study area classified their capability according to USDA (1962) into four classes II,III,VII,VIII soil in class II (profiles №.1,2,4) soil in this class have a slight limitation and conservation practices are easy to apply. These soils may be used for cultivated crops, pasture, and woodland or wildlife food. The soils have one or more limitation slight hazard of wind or water erosion, occasional damaging overflow, moderate soil depth wetness and gentle slopes. Soils in class III (profiles № 17\&19) have moderate limitations and conservation practices are usually more difficult to apply and maintain. These soils may be used for cultivated crops, pasture, range, and woodland or wildlife food. The soils have one or more limitations: moderate hazard of wind or water erosion; frequent damaging overflow; wetness; 
moderately shallow rooting depth; moderately low moisture holding capacity; low fertility not easily corrected and moderate slopes. Soil in this class (profiles No..5,12,15,16,18,20,21,22and 23) have severe one or more continuing limitations that cannot be corrected such as very steep slopes, erosion, shallow soil, stones, salt or sodium. This unit can be used safety for grazing or woodland or wildlife. While, soils in class VIII (profiles №. 6, 7, 8, 9, 5,10,11,13 and 14) have limitations preclude their use for commercial plant production. Limitations that cannot be overcome consist of one or more of the following: erosion or erosion hazard; wetness; stones and rocks; and very low moisture capacity.

\section{Land suitability}

\subsection{Current land suitability}

Applying the land suitability is classified according to FAO (2006) to the soils of the study area, Data in Table ( 14 ) reveals that, the current suitability of these soils can be placed at the following classes; class S1 (slightly suitable) which represented by profiles No. 1, 2, 4 and 5. These soils have slightly limitations that differ in their kind and degree. The $\mathrm{S} 2$ is the second class (moderately suitable) which including eight profiles (№. 3, 12, 15, 16, 20, 21, 22 and 23). These soils have moderately limitations that differ in their kind and degree. The third class S3 (marginally suitable) represented by profiles №. 7, 8, 9, 10, 11, 13, 14, 17, 18 and 19. The soils of this class are affected by moderate and severe limitations that differ in their kind and degree (unsuitable) was the last degree of suitability which represented by profiles №. 6 . This class of soil is affected by severe limitations such as depth and ESP in profile No. 6. The most limiting factors in the studied soils are profile depth, salinity index (EC), and available water (AW) while the rest limitation factors represent minor limitations.

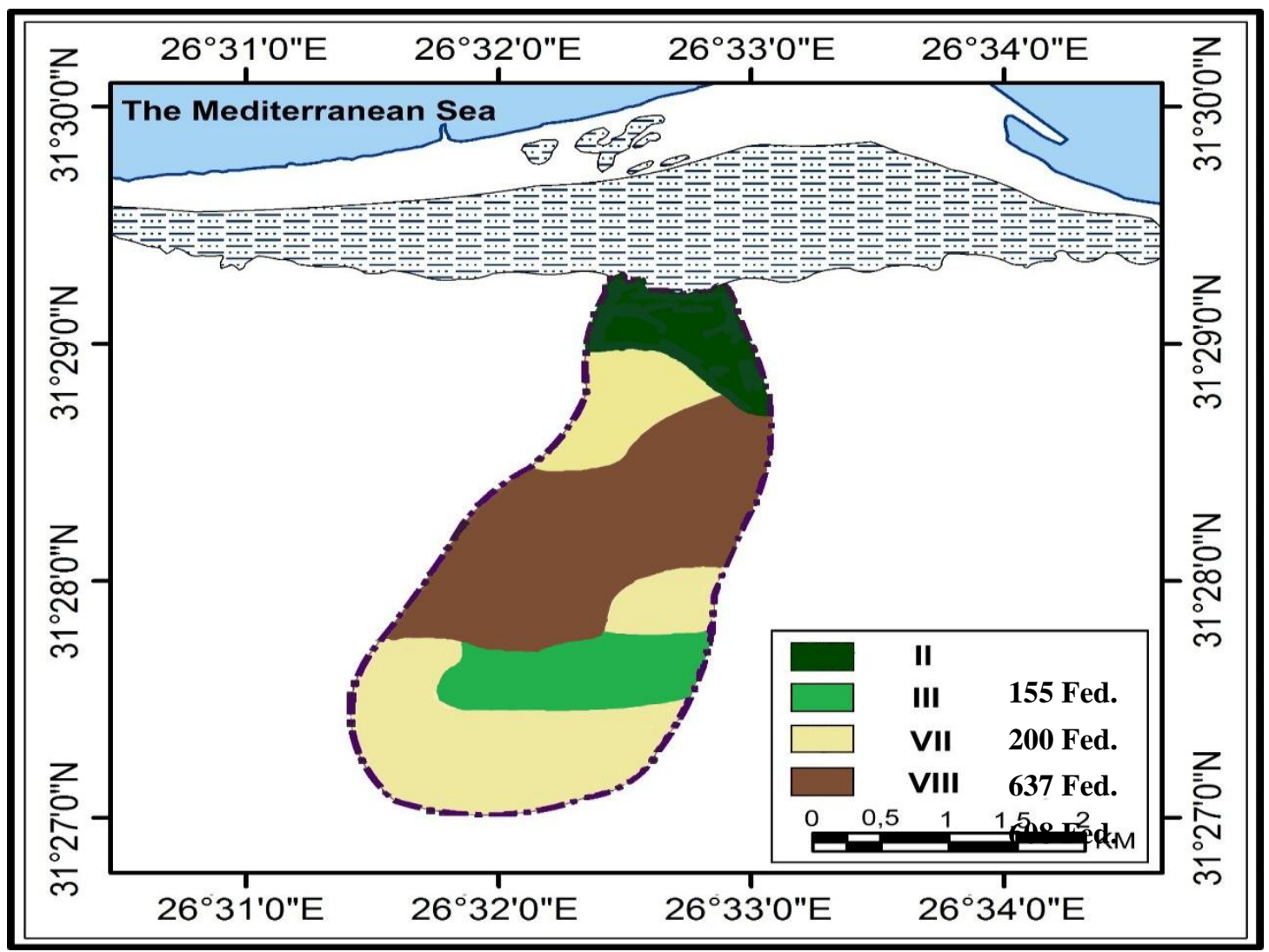

Map 4. Land capability of investigation area 
Table 14. Degree of soil limitations and suitability classes of the studied soil profiles

\begin{tabular}{|c|c|c|c|c|c|c|c|c|}
\hline il & 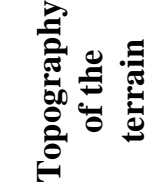 & 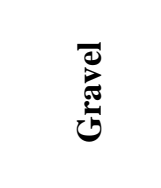 & 䓂 & $\overbrace{\tilde{ల}}^{\infty}$ & $\bigcup_{I 工 I}$ & $\hat{\bar{\Upsilon}}$ & 家 & 葛 \\
\hline 1 & Very low & Very low & Low & Low & Moderate & Very low & Moderate & S1 \\
\hline 2 & Very low & Very low & Low & Low & Very low & Very low & Moderate & S1 \\
\hline 3 & Low & Low & Low & Low & Very low & Very low & Moderate & S2 \\
\hline 4 & Very low & Very low & Low & Low & Very low & Very low & Low & S1 \\
\hline 5 & Low & Very low & Moderate & Low & Very low & Very low & Moderate & S1 \\
\hline 6 & Low & Low & Severe & Low & Very low & Very low & Severe & $\mathrm{N} 1$ \\
\hline 7 & Low & Low & Severe & Low & Very low & Very low & Low & S3 \\
\hline 8 & Low & Low & Severe & Low & Very low & Very low & Low & S3 \\
\hline 9 & Low & Very low & Severe & Low & Low & Very low & Moderate & S3 \\
\hline 10 & Low & Low & Severe & Low & Very low & Very low & Moderate & S3 \\
\hline 11 & Low & Low & Severe & Low & Very low & Very low & Moderate & S3 \\
\hline 12 & Low & Very low & Moderate & Low & Low & Very low & Moderate & S2 \\
\hline 13 & Low & Low & Severe & Low & Low & Very low & Low & S3 \\
\hline 14 & Low & Low & Severe & Low & Low & Very low & Moderate & S3 \\
\hline 15 & Low & Low & Moderate & Low & Moderate & Very low & Moderate & S2 \\
\hline 16 & Very low & Low & Moderate & Low & Very low & Very low & Moderate & S2 \\
\hline 17 & Very low & Very low & Severe & Low & Very low & Very low & Moderate & S3 \\
\hline 18 & Very low & Very low & Severe & Low & Moderate & Very low & Moderate & S3 \\
\hline 19 & Low & Very low & Severe & Low & Very low & Very low & Moderate & S3 \\
\hline 20 & Very low & Low & Moderate & Low & Very low & Very low & Low & S2 \\
\hline 21 & Very low & Low & Moderate & Low & Very low & Very low & Moderate & S2 \\
\hline 22 & Very low & Very low & Moderate & Low & Very low & Very low & Moderate & S2 \\
\hline 23 & Very low & Very low & Moderate & Low & Very low & Very low & Moderate & S2 \\
\hline
\end{tabular}

* S1 (slightly suitable), S2 (moderately suitable), S3 (marginally suitable), N (unsuitable)

\subsection{Potential land suitability}

This current suitability can be more profitable after executing the main growth limitations as agricultural mechanization to improve soil characteristics from depth, in addition continuous application of organic manure to improve soil properties and fertility status, and application of drip and sprinkler irrigation system.

Data in Table (15) showed that, profiles No. 1, 2 and 21 are slightly suitable (S1) for Alfalfa and profiles №. $8,9,11,13,15,16,17,18,19,20,22$, and 23 are moderately suitable (S2), while profiles №.3,4,5,6,7and 10 are marginally suitable (S3) for Alfalfa.

For Barley crop data showed that, profiles №.1,2,8,9,12,14,15, and 16 are S1 and profiles №. $4, \overline{7}, 10,11,17,18,19,20,21,22$ and 23 are $\mathrm{S} 2$ while profiles №. 3, 5, 6 and 13 are S3. Wheat crop showed S2 for soil profiles №.8, 11,14,18,19 \& 21 and $\mathrm{N}$ for soil profile №. 23 while the rest profiles are S3. For Maize crop profiles №.1, 2, 12, 15, 16, 20 and 21 are S1 while profiles №. 3, 4, 8,9,13,14,18,22 and 23 are S2 and the rest profiles are S3. Sorghum is considered one of the crops that gave promising results in terms of its suitability as profiles №. $8,11,13,14,18$ and 21 are S1 and profiles №. 1,2,3,4,9,10,12,15,16,17,19 and 20 are S2 while profiles №.5, 6,7 and 22 are S3 and profile No. 23 is N1. Quite the contrary, peanuts have not shown promising results in their suitability, as profiles №.12, 14 and 18 are S1 №. 1,2,16 and 17 are S2 and $7,8,9,13,20 \& 21$ are $\mathrm{S} 3$ while the rest profiles give unsuitable $\mathrm{N}$ (№. $3,4,5,6,19,22 \&$ 23). The same trend showed with cabbage, tomato and green pepper, in this respect, cabbage, only showed S1 for soil profiles №. 12,14 and 18, and recorded in profiles 9 unsuitable $(\mathrm{N})$. While tomato and green pepper never showed soil profiles $\mathrm{S} 1$ and give 15 profiles unsuitable $(\mathrm{N})$ for tomato crop and 12 profiles for green pepper. In the same time, the trees did not show promising results in suitability for the study soils, in this regard, Olive showed only four profiles S2 and S3 and Citrus showed three profiles S3, while Guava tree give the best result in this regard whereas gives 9 profiles $\mathrm{S} 3$ 
Table 15. Gross current and potential land suitability for seasonal crops and trees

\begin{tabular}{|c|c|c|c|c|c|c|c|c|c|c|c|c|c|}
\hline $\begin{array}{c}\text { Profile } \\
\text { No. }\end{array}$ & $\begin{array}{l}\text { Suitability } \\
\text { Status }\end{array}$ & 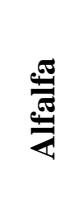 & & $\frac{\vec{E}}{\vec{E}}$ & 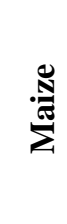 & 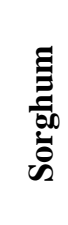 & 㤩 & 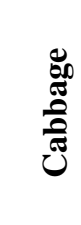 & 苞 & 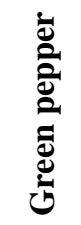 & 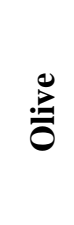 & $\sum_{0}^{\mathscr{E}}$ & ت્ \\
\hline 1 & S1 & $\mathrm{S} 1$ & $\mathrm{~S} 1$ & S3 & $\mathrm{S} 1$ & $\mathrm{~S} 2$ & S2 & S1 & S3 & S2 & S2 & S3 & $\mathrm{N}$ \\
\hline 2 & S1 & $\mathrm{S} 1$ & $\mathrm{~S} 1$ & S3 & $\mathrm{S} 1$ & $\mathrm{~S} 2$ & S2 & S2 & S3 & S2 & S2 & S3 & S3 \\
\hline 3 & S2 & S3 & S3 & S3 & S2 & $\mathrm{S} 2$ & $\mathrm{~N}$ & S2 & S3 & S3 & S3 & S3 & $\mathrm{N}$ \\
\hline 4 & S1 & S3 & $\mathrm{S} 2$ & S3 & S2 & $\mathrm{S} 2$ & $\mathrm{~N}$ & $\mathrm{~N}$ & $\mathrm{~N}$ & $\mathrm{~N}$ & $\mathrm{~N}$ & $\mathrm{~N}$ & $\mathrm{~N}$ \\
\hline 5 & S1 & S3 & S3 & S3 & S3 & S3 & $\mathrm{N}$ & $\mathrm{N}$ & $\mathrm{N}$ & $\mathrm{N}$ & $\mathrm{N}$ & $\mathrm{N}$ & $\mathrm{N}$ \\
\hline 6 & $\mathrm{~N}$ & S3 & S3 & S3 & S3 & S3 & $\mathrm{N}$ & $\mathrm{N}$ & $\mathrm{N}$ & $\mathrm{N}$ & $\mathrm{N}$ & $\mathrm{N}$ & $\mathrm{N}$ \\
\hline 7 & S3 & S3 & $\mathrm{S} 2$ & S3 & S3 & S3 & S3 & $\mathrm{N}$ & $\mathrm{N}$ & $\mathrm{N}$ & $\mathrm{N}$ & $\mathrm{N}$ & $\mathrm{N}$ \\
\hline 8 & S3 & $\mathrm{S} 2$ & $\mathrm{~S} 1$ & S2 & $\mathrm{S} 2$ & $\mathrm{~S} 1$ & S3 & S3 & $\mathrm{N}$ & $\mathrm{N}$ & $\mathrm{N}$ & $\mathrm{N}$ & $\mathrm{N}$ \\
\hline 9 & S3 & $\mathrm{S} 2$ & $\mathrm{~S} 1$ & S3 & $\mathrm{S} 2$ & $\mathrm{~S} 2$ & S3 & $\mathrm{S} 3$ & $\mathrm{~N}$ & S3 & $\mathrm{N}$ & $\mathrm{N}$ & S3 \\
\hline 10 & S3 & S3 & $\mathrm{S} 2$ & $\mathrm{~S} 3$ & S3 & $\mathrm{S} 2$ & $\mathrm{~N}$ & $\mathrm{~N}$ & $\mathrm{~N}$ & $\mathrm{~N}$ & $\mathrm{~N}$ & $\mathrm{~N}$ & S3 \\
\hline 11 & S3 & $\mathrm{S} 2$ & $\mathrm{~S} 2$ & S2 & S3 & $\mathrm{S} 1$ & S3 & S3 & $\mathrm{N}$ & $\mathrm{N}$ & $\mathrm{N}$ & $\mathrm{N}$ & $\mathrm{N}$ \\
\hline 12 & S2 & $\mathrm{S} 1$ & $\mathrm{~S} 1$ & S3 & $\mathrm{S} 1$ & $\mathrm{~S} 2$ & $\mathrm{~S} 1$ & $\mathrm{~S} 1$ & S3 & S2 & $\mathrm{N}$ & $\mathrm{N}$ & S3 \\
\hline 13 & S3 & S2 & S3 & S3 & $\mathrm{S} 2$ & $\mathrm{~S} 1$ & S3 & $\mathrm{S} 1$ & $\mathrm{~N}$ & S3 & $\mathrm{N}$ & $\mathrm{N}$ & S3 \\
\hline 14 & S3 & $\mathrm{S} 1$ & $\mathrm{~S} 1$ & $\mathrm{~S} 2$ & $\mathrm{~S} 2$ & $\mathrm{~S} 1$ & $\mathrm{~S} 1$ & $\mathrm{~S} 2$ & $\mathrm{~N}$ & S3 & $\mathrm{N}$ & $\mathrm{N}$ & S3 \\
\hline 15 & S2 & $\mathrm{S} 2$ & $\mathrm{~S} 1$ & $\mathrm{~N}$ & $\mathrm{~S} 1$ & $\mathrm{~S} 2$ & S3 & S1 & S3 & $\mathrm{N}$ & $\mathrm{N}$ & $\mathrm{N}$ & $\mathrm{N}$ \\
\hline 16 & S2 & $\mathrm{S} 2$ & $\mathrm{~S} 1$ & $\mathrm{~S} 3$ & $\mathrm{~S} 1$ & $\mathrm{~S} 2$ & $\mathrm{~S} 2$ & S1 & $\mathrm{N}$ & S2 & $\mathrm{N}$ & $\mathrm{N}$ & S3 \\
\hline 17 & S3 & $\mathrm{S} 2$ & $\mathrm{~S} 2$ & S3 & S3 & $\mathrm{S} 2$ & $\mathrm{~S} 2$ & $\mathrm{~S} 2$ & $\mathrm{~N}$ & S3 & $\mathrm{N}$ & $\mathrm{N}$ & S3 \\
\hline 18 & S3 & $\mathrm{S} 2$ & $\mathrm{~S} 2$ & S2 & $\mathrm{S} 2$ & S1 & $\mathrm{S} 1$ & $\mathrm{~S} 2$ & S3 & S3 & $\mathrm{N}$ & $\mathrm{N}$ & $\mathrm{N}$ \\
\hline 19 & S3 & $\mathrm{S} 2$ & $\mathrm{~S} 2$ & $\mathrm{~S} 2$ & S3 & $\mathrm{S} 2$ & $\mathrm{~N}$ & $\mathrm{~N}$ & $\mathrm{~N}$ & $\mathrm{~N}$ & $\mathrm{~N}$ & $\mathrm{~N}$ & $\mathrm{~N}$ \\
\hline 20 & S2 & $\mathrm{S} 2$ & $\mathrm{~S} 2$ & S3 & $\mathrm{S} 1$ & $\mathrm{~S} 2$ & S3 & $\mathrm{S} 2$ & S3 & S3 & $\mathrm{N}$ & $\mathrm{N}$ & $\mathrm{N}$ \\
\hline 21 & S2 & $\mathrm{S} 1$ & S2 & S2 & $\mathrm{S} 1$ & S1 & S3 & $\mathrm{S} 2$ & S3 & S3 & $\mathrm{N}$ & $\mathrm{N}$ & S3 \\
\hline 22 & S2 & $\mathrm{S} 2$ & $\mathrm{~S} 2$ & S3 & $\mathrm{S} 2$ & S3 & $\mathrm{N}$ & $\mathrm{N}$ & $\mathrm{N}$ & $\mathrm{N}$ & S3 & $\mathrm{N}$ & $\mathrm{N}$ \\
\hline 23 & $\mathrm{~S} 2$ & $\mathrm{~S} 2$ & $\mathrm{~S} 2$ & $\mathrm{~N}$ & $\mathrm{~S} 2$ & $\mathrm{~N}$ & $\mathrm{~N}$ & $\mathrm{~N}$ & $\mathrm{~N}$ & $\mathrm{~N}$ & $\mathrm{~N}$ & $\mathrm{~N}$ & $\mathrm{~N}$ \\
\hline
\end{tabular}

\section{REFERENCES}

Abd El-Rahman, S.M.H., Y.S. Kasim and H.A. El-Attar. 1987. Soil Taxa of North Western Coastal Region of Egypt. J. Soil Sci. 27: 11-29.

Abd El-Rahman, S.M.H., Y.S. Kasim and H.A. El-Attar. 1986. Soils of North Western Coastal Region in Land Use Classification (Egypt). J. Soil Sci.(Special Issue). 17-28.

Abd El-Rahman, S.M.H., Y.S. Kasim and H.A. EI-Attar. 1984. Soil taxa of the North Western Coastal region of Egypt. Egypt. J. Soil Sci. Cairo, under press, Academy of Scientific.

Abdel-Aal, Sh.I., M.E. Showky and R.R. Shahin. 1990.Status of $\mathrm{Mn}, \mathrm{Zn}$ and Bin relation to soil quality in some prospective Oases of thewestern desert of Egypt. Egypt. J. Soil Sci. 30:649-664.

Abdou, F.M., F.B. Labid and M. I. Michkael. 1983. Distribution ofcalcite and dolomite in some calcareous soils of Egypt. Egypt J. Soil Sci. 23:75-82.

Ali, A., T. Oweis, M. Rashid, S. El Naggar and A.A. Aal . 2007. Water harvesting options in the drylands at different spatial scales. Land Use Water Resour. Res. 7:1-13.
DRC Staff, (Desert Research Center). 2010. Development of Northwestern coastal wadies. Progressive report. DRC publications. De la Rosa, D.F. Mayol, E. Diaz-Pereira and M.

El-kady, H.A. 1970. Pedology studiesbearing on genesis and morphology of Mariut area.ph. D.Thesis, Ain shams University ,Cairo.

El-Shalzly, M.M. 1964. Geology, pedology, and hydrology of Mersa Matruh Western Mediterranean literal, U.A.R. Ph.D. Thesis, Fac. Sci.Cairo University, Cairo.

El-Shazly, E.M., M.A. Abdel Hady and M.A. ElGhawaby.1975. Geologic interpretation of LANDSAT satellite images for west Nile Delta area, Remote sensing research project. Academic of scientific research and tecknology, Cairo, Egypt.

FAO .2006. Guidelines for soil profile description. 4th ed. FAO Publications, Rome.

FAO. 1970. Pre investment survey of the northwestern coastal region. ESE : SF/UAR 49. 
Harga, A.A. 1967. Some physico-chemical studies of Burg el Arab ,El Hammam Area. M.Sc Thesis, Faculty of Agric. Ain Shams Univ. Egypt U.A.R.

Jackson, M. L. 1963. Soil chemical analysis. constable and Co. Ltd., England.

Jackson, M.L. 1973. Soil chemical analysis. Advanced course Ed.2. A Manual of methods useful for instruction and research in soil chemistry, physical chemistry of soil, soil fertility and soil genesis. Revised from Original Edition (1955).

Kilmer, V. I and L.T. Alexander. 1949. Methods of making mechanical analysis of Soils .Soil Sci. 68:15-24.

Nassem, M.G., M.A. Hussein and K.A. Abdl Gader. 2008. Comparative Study on Salinity Measurements in Soils of the North Western Coastal Region of Egypt. Alex. Sci . Exch. J. 29: 45-54.

Olsen, S.R., C.V. Cole, F.S. Watanbe and L.A. Dean. 1954. Estimation of Available phosphorus in soils by extraction with sodium bicarbonate .U.S. Dept. of Agric.Cairo, (C.F.FAO. Soils Bul.1980)

Pautsch, G.R and A.H. Abdelrahman.1998. Effects of Egyptian economic reforms: the horticultural sector. Food Policy. 23(2):199-210.

Piper, C.S. 1950. Soil and plant analysis, Inter. Science papl. Inc. New York, USA. press (clarendon), London and New York.
Richards, L.A. 1954. Diagnosis and improvement of saline and alkali soils. U.S.D.A. Handbook, No. 60, Washington, C.D., U.S.A.

Shaaban, F.F. 2010. Vertical electrical sounding for groundwater investigation in northwestern Egypt: a case study in a coastal area. African Earth Sciences. (33) 673686.

Shata, A. 1971. Geomorohology, pedology, and hydrology of the Med. coast desert of UAR. Symposium on the Geology of Libya.431-446.

Soltanpour, P.N and A. P. Schwab. 1977. Anew soil test simultaneous extraction of macro- and micro -nutrients in alkaline soils. Commun. Soil Sci .Plant Anal. 8: 195-207.

USDA. 1962. Land capability classification, Soil conservation service.

Yousif, M. 2014. Integration of the geomorphologic and geologic studies for water potentialities development in El Zarraqa and El Harraqa basins, East Matrouh, northwestern coast, Egypt. Arab J. Geosci. 8:4603-4626. doi:10.1007/s12517-014-1522-8

Yousif, M., T. Oguchi, K. Anazawa and T. Ohba. 2015. Framework for investigation of karst aquifer in an arid zone, using isotopes, remote sensing and GIS applications: the Northwestern Coast of Egypt Environ. Process. 2:3760. DOI 10.1007/s40710-015-0063-9. 


\section{الملخص العربي \\ تقسيم وتقييم اراضى وادى ابو عميرة-غرب مطروح الساحل الشمالى الغربى سمصر \\ جيهان محمد عبيد عبد المولي و طاهر مصطفي حامد يوسف}

قوام طمي رملي أو طيني رملي. تعنبر معظم المناطق غير ملحية إلى قليلة الملوحة والمنطقة المدروسة عبارة عن معثدلة الكلسية إلى عالية. وبحسب وزارة الزراعة الأمريكية (r 97 ( ) ، فقد صنفت قدرة التربة الإنتاجية لمنطقة الدراسة إلى أربع

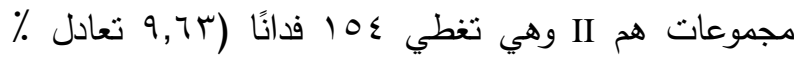
من المساحة) ، و III وهي تغطي 199 و فدانًا (تعادل

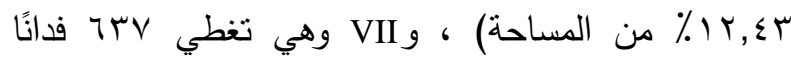

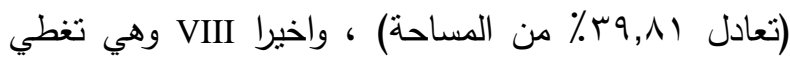

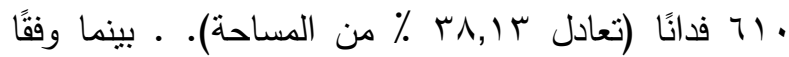
لمنظمة الأغذية والزراعة (T ( . †) ، يمكن وضع صلاحية

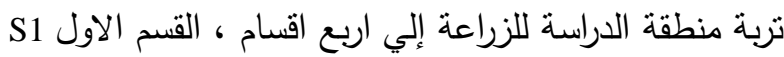

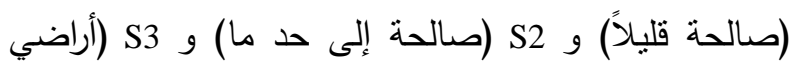
هامشية) و N (غير مناسبة للزراعة). وذللك في ضوء نوعية المحدات المدروسة وهي عمق القطاع الارضي، وملوحة التربة (EC) ، والمياه المتاحة (AW) بينما تمنل بقية العوامل المحددة قيودًا طفيفة.

الدراسة الحالية عبارة عن تجربة لتقييم إمكانات التربة في هذه المنطقة من حيث تصنيف قدرة الأرض. وسيكون هذا العمل مفيدًا في المستقبل باعتباره أساسًا لسياسة التتمية الزراعية في تلاك المنطقة. الكلمات المفتاحية: تكوين الأراضي، تقسيم الأراضي ، امكانات التربة، قدرة التربة، ملائمة التربة
تعتبر منطقة الساحل الثمالي الغربي لمصر من أكثر المناطق الواعدة للتتمية الزراعية والتي تتميز بتوفر جميع موارد ومكونات التتمية فيها. أجريت الدراسة على موقع وادي لئي أبو عميرة بالساحل الثمالي الغربي لمصر غرب مدينة مرسى مطروح بغرض تحديد انواع الأراضي السائدة في منطقة الدراسة وتقسيمها وتعبين قدرتها الانتاجية. تشغل منطقة الدراسة مساحة . . 1 1 فدان وتم تحديد الأثكال الأرضية بإستخدام الخرائط الجيومورفولوجية والطوبغرافية. تم اختيار ثلاثة وعشرين قطاع لتمثيل وحدات التشكيل الأرضي الرئيسية في دراسة التربة. يمكن تصنيف منطقة الدراسة من خلال رتبتين هما (Entisols و .Aridisols). والتحت مجموعات لرتبة lithic , Typic haplocalcids هAridisols Typic Torripsamments gTorripsamments التشخيصية لرتبة Aridisls هي آفاق كلسية بينما تعتبر أفاق رتبة Entisols أقل تطورًا. وبناءا على صفات عمق القطاع الأرضى وقوام التربة وطبوغرافية السطح قسمت أراضى المنطقة إلي ثلاث وحدات ، قطاع تربة عميق وذات قوام خشن إلى متوسط الخشونة و منوسط العمق ذات قوام خشن إلى منوسط الخشونة واخيراً ضحل ذا تربة خثنة إلى حد ما. أظهرت الفحوصات الميدانية أن .,11\% من مساحة الدراسة ذات قطاعات

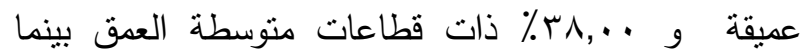

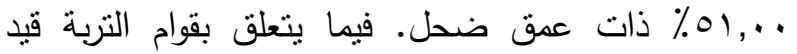

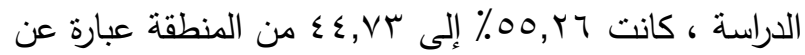
طميية رملية إلى تربة رملية طينية وبقية المنطقة إما ذات 